\title{
RANCANGAN PEMBUATAN MESIN PENGAYAK PASIR UNTUK MENINGKATKAN PRODUKTIVITAS KERJA OPERATOR
}

\author{
Ary Perdana ${ }^{* \star}$ ) dan Rusdiyantoro *)
}

\begin{abstract}
Abstrak
Dalam proses pembuatan rumah atau gedung sudah tentu membutuhkan material atau bahan bangunan. Salah satu material yang digunakan dalam proses pembuatan tersebut adalah pasir. Pasir merupakan material yang tidak bisa dipisahkan dari dunia industry perumahan atau bangunan. Pasir ini dicampur dengan semen untuk proses pembuatan cor tiang maupun dinding tembok. Pasir yang dimaksud disini adalah pasir yang siap dipakai, pasir yang diambil langsung masirh tercampur dengan kerikil dan bebatuan. Dalam hal ini penelitian ini difokuskan pada pengayakan pasir dari pengayakan konvensional ke pengayakan dengan menggunakan mesin. rancangan pembuatan mesin pengayak pasir untuk meningkatkan produktifitas kerja operator. Seberapa besar penggunaan mesin ini untuk meningkatkan produktifitas kerja operator mesin pengayak pasir. Berdasarkan hasil penelitian ini bahwa produktifitas kerja opertaor mesin penyayak pasir mengalami peningkatan dibandingkan dengan menggunakan cara konvensional. Adapun uji ini lakukan dengan menggunakan penghitungan waktu tahap pertama pasir $10 \mathrm{~kg}$ waktu yang dibutuhkan 8 menit: 4 menit dengan opertor 2:1 orang dari analisa tersebut bahawa terdapat peningkatan produktifitas denga nilai penghematan 1/2 dibandingkan dengan pengayakan konvensioanal dan ini dapat mengurangi biaya tenaga kerja kerena menggunakan 1 opertor.
\end{abstract}

Kata kunci: Mesin Pengayak Pasir, Operator, Pasir, Produktifitas Kerja.

\section{Pendahuluan}

Pasir merupakan material yang sangat dibutuhkan dalam proses pembuatan gedung maupun rumah. Pasir ini tidak lepas dalam dunia indurti yang sangat erat dengan industry perumahan. Material pasir ini biasaynga masih tercampur dengan batu atau kerikil. Untuk mendapatkan material pasir yang halus ini maka dilakukan proses pengayakan. Proses pengayakan ini dengan tujuan untuk mendapatkan pasir yang siap digunkan dalm proses selanjutnya.

Proses pengayakan ini masih menggunakan alat konvensional dengan 2 orang sebagai operator hal ini tentu akan membutuhkan biaya dan waktu yang cukup besar untuk membuat suatu bangunan, oleh karena itu penelitian ini dititik beratkan bagaimana merancang mesin pengayak pasir yang dapat meningkatkan prosuktufitas kerja operator dengan tujuan agar proses pengayakan mengalami peningkatan terhadap hasil pengayakan pasir serta dengan operator yang seminim mungkin. Hal ini dilakukan untuk meminimalisir biaya yang dikeluarkan. Penelitian ini tentu menggunaka beberapa teori yang relevan dalam proses rancangan pembuatan mesin pengayak pasir.

$$
\text { Menurut Wikipedia bahasa }
$$

Indonesia, Pasir adalah contoh bahan material butiran. Butiran pasir umumnya berukuran antara 0,0625 sampai 2 milimeter. Materi pembentuk pasir adalah silikon dioksida, tetapi di beberapa pantai tropis dan subtropis umumnya dibentuk dari batu kapur. Pasir memiliki warna sesuai dengan asal pembentukanya. Pasir merupakan material poko mualia dari pekerjaan rumah, saluran, pagar, gedung, dan berbagai jenis bangunan/konstruksi lainnya, hampir semua menggunakan material pasir. Berdasarkan kegunaannya, pasir bisa di bedakan menjadi Pasir pasang, biasanya dipergunakan untuk pekerjaan pasangan dinding, pondasi, pasangan batu kali, plesteranPasir beton, dipergunakan untuk pekerjaan pembetonanan, seperti plat, kolom, balok, dsb dan Pasir urug, dipergunakan untuk pekerjaan lapis dasar, pondasi, lantai atau galian, biasanya untuk pekerjaan yang tidak terkait dengan konstruksi. Teroti lain yang digunakan produktivitas.

\footnotetext{
**) Mahasiswa Teknik Industri

*) Dosen Teknik Industri

Universitas PGRI Adi Buana Surabaya
} 


\begin{abstract}
Produktivitas ialah terdapatnya korelasi "terbalik" antara masukan dan luaran. Artinya, suatu sistem dapat dikatakan produktif apabila masukan yang diproses semakin sedikit untuk menghasilkan luaran yang semakin besar. Produktivitas berasal dari kata "produktiv" artinya sesuatu yang mengandung potensi untuk digali, sehingga produktivitas dapatlah dikatakan sesuatu proses kegitan yang terstruktur guna menggali potensi yang ada dalam sebuah komoditi/objek. Filosofi produktivitas sebenarnya dapat mengandung arti keinginan dan usaha dari setiap manusia (individu atau kelompok) untuk selalu meningkatkan mutu kehidupannya dan penghidupannya.Secara umum produktivitas diartikan atau dirumuskan sebagai perbandingan antara keluaran (output) dengan pemasukan (input), sedangkan menurut Ambar Teguh Sulistiani dan Rosidah (2003:126)

kerja manusia, yakni jam-jam kerja yang harus dibayar dan jam-jam kerja yang dipergunakan untuk bekerja. Jam kerja yang harus dibayar meliputi semua jam-jam kerja yang harus dibayar, ditambah jamjam yang tidak digunakan untuk bekerja namun harus dibayar, liburan, cuti, libur karena sakit, tugas luar dan sisa lainnya. Jadi bagi keperluan pengukuran umum produktivitas tenaga kerja kita memiliki unitunit yang diperlukan, yakni: kuantitas hasil dan kuantitas penggunaan masukan tenaga kerja (Sinungan, 2003, p.24-25).

Berdasarkan teori yang digunakan maka untuk terdapat masalah penelitian ini yaitu bagaimana membuat rancangan alat pengayak pasir untuk meningkatkan produktifitas kerja operator. dengan tujian untuk mengetahui tingkkat produktifitas kerja operator mesin pengayak pasir. Dengan pembuantan rancangan ini diharapkan dapat meningkatkan nilai produktifitas.
\end{abstract} mengemukakan bahwa produktivitas adalah "Menyangkut masalah hasil akhir, yakni seberapa besar hasil akhir yang diperoleh didalam proses produksi, dalam hal ini adalah efisiensi dan efektivitas". Sedangkan menurut Malayu S.P.Hasibuan (2003:126) produktivitas adalah :"Perbandingan antara output (hasil) dengan input (masukan). Jika produktivitas naik ini hanya dimungkinkan oleh adanya peningkatan efesiensi (waktu,bahan,tenaga) dan sistem kerja, teknik produksi dan adanya peningkatan keterampilan dari tenaga kerjanya". Dari beberapa pendapat tersebut diatas sebenernya produktivitas memiliki dua dimensi, pertama efektivitas yang mengarah kepada pencapaian untuk kerja yang maksimal yaitu pencapaian target yang berkaitan dengan berkualitas, kuantitas, dan waktu. Kedua yaitu efesiensi yang berkaitan dengan upaya membandingakan input dengan realisasi penggunaanya atau bagaimana pekerjaan tersebut dilaksanakan.

Pengukuran produktivitas tenaga kerja menurut system pemasukan fisik perorangan/perorang atau per jam kerja orang diterima secara luas, namun dari sudut pandangan/ pengawasan harian, pengukuran-pengukuran tersebut pada umumnya tidak memuaskan, dikarenakan adanya variasi dalam jumlah yang diperlukan untuk memproduksi satu unit produk yang berbeda. Oleh karena itu, digunakan metode pengukuran waktu tenaga kerja (jam, hari atau tahun). Untuk mengukur suatu produktivitas perusahaan dapatlah digunakan dua jenis ukuran jam

\section{Metode penelitian}

Rancangan penelitian ini adalah rancangan penelitian eksperimen. Rancangan eksperimen yaitu suatu rancangan percobaan dengan setiap langkah tindakan yang terdefinisikan, sehingga informasi yang berhubungan dengan atau diperlukan suatu persoalan yang akan diteliti dapat dikumpulkan secara faktual (Juliansyah noor, 2011). Teknik pengambilan sampling menggunakan purposive sampling yaitu teknik penentuan sampel dengan pertimbangan tertentu ( Sugiyono, 2011). Sampel penelitian ini adalah alat pengayak pasir. Metode pengumpulan data dengan metode literature, observasi dan eksperimen. Sedangkan metode analisa menggunakan Analisis bahan, Analisis biaya produk dan Analisis produktifitas kerja operator.

\section{Hasil Penelitian}

Penelitian ini dilakukan Wilayah Desa Tamping Mojo. Gambaran desa ini berada dikecamatan Tembelang kabupaten Jombang, Jawa Timur. Luas daerah desa ini mencapai 217.182 ha dengan luas permukiman 66.770ha tegal 0,565 ha, sawah 122.218 ha dan lainya 28.059. Dalam tahun trakir ini pembangunan desa ini mengalami peningkatan terutama pada infratruktur jalan maupun jembatan. Pembangunan rumahpun meningkat. Ini didasarkan pada rumah yang terkena dampak tol Surabaya - ke jateng yang sedang berlangsung. 
Jumlah penduduk didesa ini mencapai 4.629 jiwa dan kk 1.634 berdasarkan data geografis luas daerah tahun 2013. Profesi penduduk didesa ini berbagai macam profesi diantaranya: petani , guru, sopir, buruh pabrik dan PNS.

Desain rancangan mesin pengayak pasir ini dapat dilihat gambar dibawah ini dengan beberapa tahapan pembuatan desain yang penggambaranya dilakukan dengan bantuan software autocad.

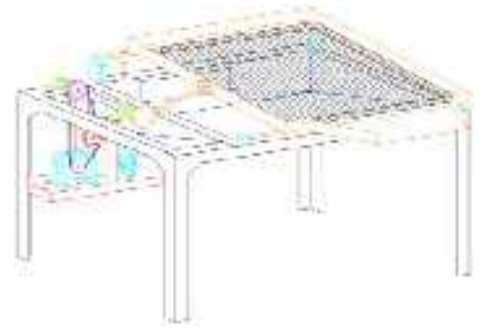

Gambar: 1. Mesin pengayak pasir

Mesin pengayak pasir ini dibuat dengan besi siku dengan ukuran50x50mm,dengan panjang mesin $1200 \mathrm{~mm}$ lebar $700 \mathrm{~mm}$ dan tnggi mesin $900 \mathrm{~mm}$.

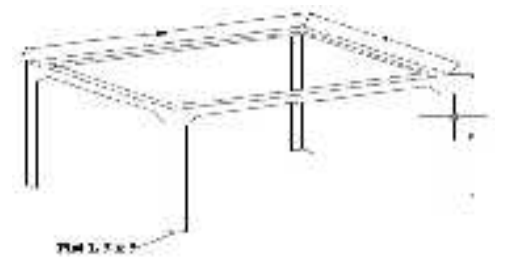

Gambar: 2. Kerangka mesin pengayak pasir Kerangka mesin pengayak pasir ini dibuat dari besi siku ukuran $50 \times 50 \mathrm{~mm}$ dengan panjang $1200 \mathrm{~mm}$ lebar $700 \mathrm{~mm}$ dan tinggi $750 \mathrm{~mm}$.

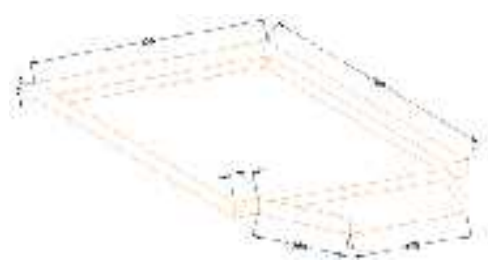

Gambar: 3. input pengayak pasir

Kerangka $750 \mathrm{~mm}$ lebar $700 \mathrm{~mm}$ dan diberi tambahan dengan ukuran panjang $375 \mathrm{~mm}$ dan lebar $300 \mathrm{~mm}$ di buat dengan kemiringan 30 derajat biar lebih mempercepat proses produksi. input pengayak pasir ini terbuat dari besi siku dengan ukuran $50 \times 50 \mathrm{~mm}$ dengan panjang

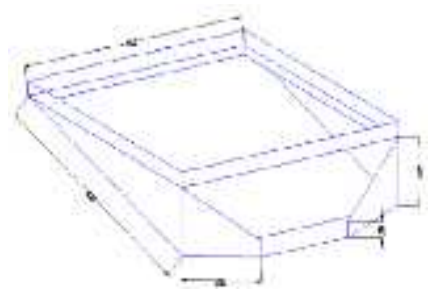

Gambar: 4. Output pengayak pasir

Kerangka output ini terbuat dari besi siku dengan ukuran 50x50mmdengan panjang $910 \mathrm{~mm}$ lebar $700 \mathrm{~mm}$ dan diberi tambahan kebawah dengan ukuran panjang $820 \mathrm{~mm}$ dan $330 \mathrm{~mm}$ dibuat dengan kemiringan 50 derajat sehingga lebih cepat proses produksinya.

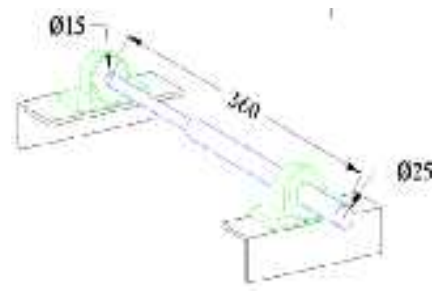

Gambar: 5. Poros bearing

Kerangka poros ini terbuat dari besi poros yang mempunyai panjang $360 \mathrm{~mm}$ diameter ujungnya berdiameter $23 \mathrm{~mm}$ dan sisi lainya berdiameter $25 \mathrm{~mm}$.

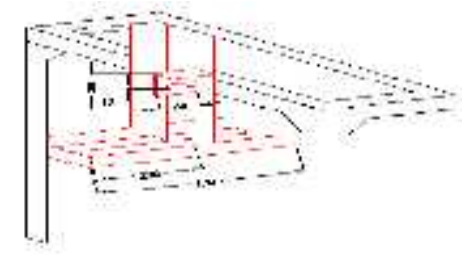

Gambar : 6. Dudukan motor, gearbox dan stelan vanbelt

Desain dudukan motor dan gear box ini terbuat dari besi siku dengan ukuran $40 \times 40 \mathrm{~mm}$, panjang $450 \mathrm{~mm}$ dan tinggi $500 \mathrm{~mm}$ sedangkan untuk setelan vanbelt terbuat dari besi siku ukuran $50 \times 80 \mathrm{~mm}$ dengan ukuran panjang $90 \mathrm{~mm}$ dengan lebar lubang baut $15 \mathrm{~mm}$.

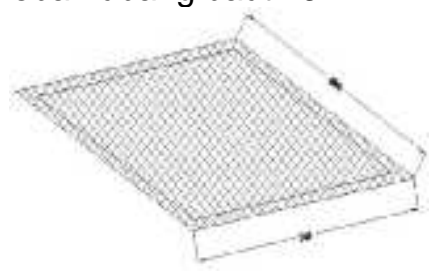

Gambar.4.7 kasa ayak pasir 
Kasa ayak pasir yang tepinya dibuat dari besi plat dengan ketebalan 5mmlebar $25 \mathrm{~mm}$ dengan dimensi panjang $740 \mathrm{~mm}$ dan lebar $680 \mathrm{~mm}$,dan kasanya dibuat dari kasa kawat pada umumnya dengan ukuran lubang $6 \mathrm{~mm} 2$.

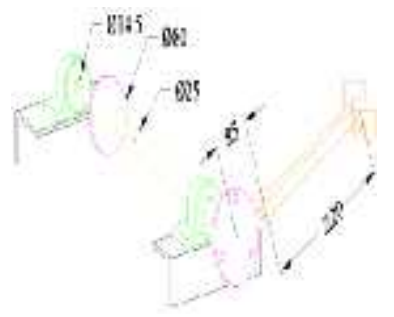

Gambar: 8. Penggerak ayak pasir

Penggerak ayak pasir ini terdiri dari bearing yang berukuran diameter $14,5 \mathrm{~mm}$ dan $22 \mathrm{~mm}$,dengan pully yang terbuat dari besi cor yang berdiameter $80 \mathrm{~mm}$,pully lengan ayun yang terbuat dari besi plat dengan ketebalan $4 \mathrm{~mm}$ yang berdiameter $85 \mathrm{~mm}$, setang lengan ayun terbuat dari kanal $C$ dengan ukuran $12 \times 12 \mathrm{~mm}$ dengan panjang $220 \mathrm{~mm}$.

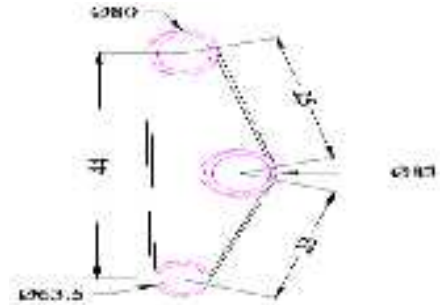

Penggerak pully menggunakan vanbelt dengan ukuran A40,pully yang dipasang adalah pully dengan diameter $63,5 \mathrm{~mm}, 80 \mathrm{~mm}$ dan untuk setelan $83 \mathrm{~mm}$,jarak antara pully gearbox dengan pully penggerak $440 \mathrm{~mm}$. Pully setelan berguna untuk mengencangkan vanbelt yang kendur.

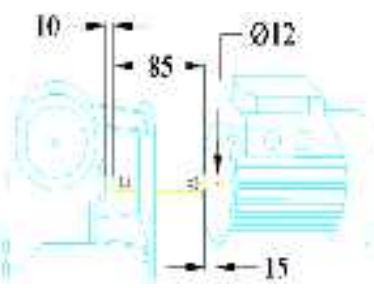

Gambar: 10. Penggerak mesin

Penggerak mesin ini dikendalikan dengan gearbox yang terbuat dari besi cor dengan perbandingan 1:30 putaran.motor menggunakan motor AC 0,5 PK.Gearbox dan motor disambungkan dengan pipa poros dengan panjang $85 \mathrm{~mm}$ yang mempunyai diameter dalam $10 \mathrm{~mm}$ dan diameter luar

$12 \mathrm{~mm}$.Jarak antara gearbox dan motor dengan pipa poros adalah $15 \mathrm{~mm}$. Kebutuhan bahan dalam pembuatan mesin pengayak pasir ini telebih dahulu mengindentifikasi kebutuhan bahan yang diperlukan. Adapun kebutuhan bahan dapat dilihat dalam tabel dibawah ini

Tabel 1: Kebutuhan Bahan Utama

\begin{tabular}{llcc}
\hline No & \multicolumn{1}{c}{ Nama bahan } & Satuan & Jumlah \\
\hline 1 & Besi siku & Meter & 12 \\
2 & Motor ac & Pcs & 1 \\
3 & Gear boxs & Pcs & 1 \\
4 & Kawat kasa & Meter & 4 \\
5 & Bearing & Pcs & 2 \\
6 & Beton Eser & Meter & 6 \\
7 & Poros & Pcs & 1 \\
8 & Baut & Kg & 2 \\
9 & Plat 0,8mm & Lembar & 1 \\
\hline
\end{tabular}

Berdasarkan tabel diatas menunjukan bahwa bahan utama pembuatan mesin pengayak pasir terdapat 9 item kebutuhan bahan utama, dimana masing -masing memiliki jumlah yang berbeda- beda.

Langkah awal dalam pembuatan mesin ini yaitu dilakukan dengan mendindentifikasi kebutuhan bahan yang akan digunakan pembuatan mesin. Indentifikasi ini penting dan harus dilakukan karena untuk mengetahui bahan apa yang sesuia dengan spesifiksi dan kekuatan mesin tersebut. Dan juga untuk mengetahui apakah bahan yang dibutuhkan tersedia di pasar. Indentifikasi ini bertujuan untuk mendapatkan bahan -bahan yang sesuai dengan spesifikasi dan standart produk. Setelah melakukan indentifikasi bahan langkah- langkah selanjutnya yaitu proses prosduksi mulai dari pemotongan bahan 
hingga finishing sesuai dengan disain yang telah dibuat sebelumnya.

Berdasarkan Analisis bahan mesin pengayak pasir ini mengalami kendala pada pembutan posos, ini disesbkan toko material tidal menyediakan material ini sesuai dengan spesifikasi yang ada. Sehingga pembuatan poros ini dilakukan di tukang bubut sendiri.berdasarkan penghitungan biaya yang dikeluarkan untuk proses pembuatan mesini ini makan total biaya adalah Rp.1.690.000,- sertav Analisis produktifitas tenaga kerja operator mesin pengayak pasir

Tahapan uji mesin ini dilakukan dengan membandingkan antara pengayak konvensional dengan 2 operator dan mesin pengayak hasil eksperimen dengan 1 operator.

Tabel 2 : Pengujian Pengayakan Konvensional Dan Pengayakan Mesin

\begin{tabular}{llllll}
\hline No & Berat pasir & \multicolumn{2}{l}{ Waktu yang dibutuhkan } & \multicolumn{2}{l}{ Jumlah operator } \\
& & Konvensional & mesin & Konvensional & mesin \\
\hline 1 & $10 \mathrm{~kg}$ & 8 menit & 4 menit & 2 orang & 1 orang \\
2 & $20 \mathrm{~kg}$ & 16 menit & 8 menit & 2 orang & 1 orang \\
\hline
\end{tabular}

hasil pengujian pengayakan pasir yang dijadikan pedoman untuk mentukan produktifitas kerja operator. Dan dari pengujian ini terdapat penghematan waktu dan dan tenaga kerja yaitu 1:2. Dimana hal ini dapat dikatakan mesin ini produktif.

\section{Pembahasan}

Berdasarkan hasil penelitian terhadap rancangan mesin pengayak pasir ini nialai produktifitas meningkat $1: 2$ dibandingan dengan penggunakan alat konvensional hal ini menunjukan bahwa teori produktifitas sangat relevan dengan rancangan mesin pengayak pasir ini. Secara umum produktivitas diartikan atau dirumuskan sebagai perbandingan antara keluaran (output) dengan pemasukan (input). produktivitas merupakan perbandingan antara keluaran serta masukan serta mengutarakan cara pemanfaatan baik terhadap sumbur-sumber dalam memproduksi suatu barang atau jasa. Menurut Wignjosoebroto, (2000, p.25), produktivitas secara umum akan dapat diformulasikan Produktivitas= Output/input(measurable)+ input (invisible). Jadi produktifitas adalah total keluaran yang dihasilkan. Sehingga dalam penelitian ini bahwa mesin pengayak pasir mengalami peningkatan produktifitas dengan penghematan waktu $1 / 2$ dari pada alat konvensional dan penghematan jumlah tenaga kerja 1 orang. Hal ini akan mengurangi pengeluaran biaya tenga kerja operator dan hasil pengayakan mengalami peningkatan dengan penghitungan per jam dapat menghasilkan $150 \mathrm{~kg}$ pasir ayakan halus.

\section{SIMPULAN DAN SARAN Simpulan}

Hasil pengujian dengan membandingankan hasil output maka terjadi peningkatan yang positif dengan alat konvensional. simpulan dari rancangan mesin pengayak pasir ini adalah Mesin pengayak pasir mengalami nilai positif terhadap produktifitas dengan peningkata $75 \mathrm{~kg}$ perjam dengan penghematan tenaga kerja operator 1 orang dan rancangan mesin pengayak pasir ini dapat berfungsi dengan baik.

\section{Saran}

Disarankan dalam pembuatan rancangan produk dialakukan perencanaan terutama kebutuhan bahan yang akan digunakan untuk proses produksi, Perhatikan kebutuhan terhadap produk yang dibuat supaya produk tersebut dibutuhkan masyarakat dan selanjutnya dalam pembuatan rancangan mesin pengayak pasir ini mempertimbangkan kapasitas perjam-nya untuk mendapatkan nilai produktifitas yang tinggi dengan biaya investasi yang rendah.

\section{DAFTAR PUSTAKA}

Arman Hakim Nasution, 2005. Manajemen Industri. Penerbit C.V Offset Yogyakarta

Gempur Santoso, 2005. Metodologi penelitian kuantitatif dan kualitatif, Penerbit Prestasi Pustaka, Jakarta.

Noor, Juliansyah., 2011. Metodologi penelitian : skripsi, tesis, disertasi, dan karya ilmiah, penerbit kencana, Jakarta 
Ary Perdana \& Rusdiyantoro : Rancangan Pembuatan Mesin Pengayak Pasir Untuk Meningkatkan Produktivitas Kerja Operator

Poniman , 2012 Disain Pembuatan Alat Penggiling Daging Dengan Quality Function Deployment, Surabaya. Tugas Akhir, Jurusan Teknik Industri Universitas PGRI Adi Buana Surabaya

Purnomo, Hari., 2004. Pengantar teknik Industri penerbit. Graha IImu, Yogyakarta.

Rosnani, Ginting., 2010. Perancangan Produk. Penerbit Graha ilmu, Yogyakarta.

Sugiyono, 2010. Satatistik untuk penelitian Penerbit Alfabeta, Bandung.

Sugiyono, 2011. Metode penelitian kuantitatif, kualitatif dan $R \& D$, Penerbit Alfabeta, Bandung. 